\title{
INVESTIGATING THE STRATEGIES TO INCREASE SOCIAL INTERACTIONS WITH SOCIAL SUSTAINABILITY APPROACH (CASE STUDY: THE STREET OF CHAHAR BAGH IN ESFAHAN)
}

\author{
Shiva Mousavi \\ M.A student in Architecture, School of Architecture and Urban Planning, Khorasegan branch, \\ Islamic Azad University, Isfahan, Iran \\ Seyed Mohammad Rashtian \\ Assistant Professor and Faculty Member of Khorasegan branch, Islamic Azad University, Isfahan, \\ Iran
}

\begin{abstract}
Public space is an opportunity to develop one's social dimensions in terms of social interaction and the experience of participation in collective life in cities. Urban public spaces as the third place that play a major role in social interaction, should be eligible for structural features and design criteria. Urban public spaces pave the way for collective and privacy identities that all residents can pay for social interaction in this area. They also provides places for dialogue and reflection and basic necessity in urban development plans. In other words, urban spaces are a part of the city that as public arena is the manifestation of urban activities. In the meantime, citizens as public activists and users of urban spaces interact in public spaces. This article by identifying variables affecting citizens' satisfaction with public spaces, has examined the indicators and criteria influencing it. It also by using a descriptive-analytic method and documentary study has investigated the definitions and concepts of urban public spaces and factors affecting the content and physical function at the Chahar Bagh Street at top of Esfahan as a influential urban public space and finally, provides tips from the perspective of local identity and convenient access to services for citizens in urban areas.
\end{abstract}

Keywords: urban spaces, social interactions, local identity, Chahar Bagh Street

\section{INTRODUCTION}

Many urban planning theorists believe that urban spaces as a key component of healthy city has a major role in urban planning and development. On the eve of the third millennium urban public spaces as third place (Carmona, \& Heath, and Tysdl, 2003) that plays a major role in establishing social interaction has been considered seriously and has become the focus of knowledge - profession of urban design. Urban spaces are places that belong to all citizens and are not limited to the physical aspects and actually, they find meaning with human presence and activity (Kashanijo, 2010). Jane Jacobs believes the presence of people in urban areas subsequently raises issues such as social safety and security. Reliance on public opinion in the design of urban space, creating spatial closeness and increased density, mixing and efficiency of space and organization, and the appropriate use are sustainable and qualitative aspects of public arena. Public space should be safely open to all classes, age groups and gender and social minorities at all hours of the day and at the same time facilitates the access and travel. The main function of public space is providing and strengthening the presence of the people therefore, its social and cultural dimensions have special place. Considering the presence of humans in urban spaces and creating human-oriented structures in the city has ancient history in urban history which has been one of the factors of the lively environment shaping throughout the history. Space and society are two inseparable elements in such a way that paying attention to one of them alone would be extremely difficult. People and space are actually a bilateral process and actually, people create and alter spaces and spaces influence people. Urban space is not only a physical concept but also it also covers the interactions between citizens and urban activities namely, it manifests the corpus of the city that is a place for urban activities or an area of social interaction. In other words, the main condition of the public spaces is that the social interaction and intercourse takes place over there (Rastbin, 2012). 
Todays, in many cities of Iran public areas are often not responsive to human needs as a social being properly and people look only to urban areas as a way to pass. Spaces instead of being a place for the constant presence of people encourage them to go and this causes the experience of dealing with others, the sense of belonging to the community, face-to-face meetings, social interaction and the experience of seeing and being seen do not happen properly. Urban planners by considering the needs and desires of the people and through the available tools can provide an environment where the presence of people is highlighted.

\section{BACKGROUND OF STUDY}

Over the last 50 years, sustainability in urban areas is proposed as one of the topics discussed in urbanization during the twentieth century. One of the first scholars who have shown interest in the environmental issues in urban areas, is Serge Chermayeff. In his view, private car destructs the human life. He divided the areas of public life and private life into six categories: urban public spaces (urban parks, highways), semi-public urban spaces (municipal building, passenger terminal, parking), especial public spaces, special private spaces (public gardens, warehouses), private family spaces, private spaces of person. He even offered rental bicycle for dense spaces within the cities. After the introduction of sustainable development approach in the early 1990s, different theorists focus on various aspects such as Graham Haughton and Colin Hunter who in the book "Sustainable Cities" emphasized on the constructive relations among buildings, open spaces and paths and in other words, on the integrity between the uni-foundation scale design and urban planning as the sustainability creating factor. Hook Barton in his book "Sustainable settlements" refers to the features that sustain human settlements and considers the existence of the open spaces network essential for pollution management, wildlife, energy, water, sewage and creating local green spaces. Richard Rogers is the other expert with a focus on sustainability that in his work entitled "Cities for a Small Planet" introduces public area as the factor of social disconcerting and mobility in cities. Because he believes that a sustainable city should have features such as justice, beauty, creativity, ecology, compactness and multi-centrality, diversity and ultimately, easy communication that information to be exchanged both in face to face and electronic mode (Carmona, \& Tizol, 2007). In Table 1, the profile of the most important experts with sustainability and environmental considerations is displayed.

Table 1. Experts with sustainability and environmental considerations (Kashanijo, 2010).

\begin{tabular}{|l|l|l|l|l}
\hline Row & Theorist & Year & $\begin{array}{l}\text { Title of text / } \\
\text { theory }\end{array}$ & Key Concepts \\
\hline 1 & $\begin{array}{l}\text { Serge } \\
\text { Chermayeff }\end{array}$ & 1964 & $\begin{array}{l}\text { Areas of } \\
\text { public life and } \\
\text { private life }\end{array}$ & $\begin{array}{l}\text { Considering the factors } \\
\text { threatening the human } \\
\text { environment in cities }\end{array}$ \\
\hline 2 & $\begin{array}{l}\text { Graham } \\
\text { Haughton and } \\
\text { Colin Hunter }\end{array}$ & 1994 & $\begin{array}{l}\text { Sustainable } \\
\text { Cities }\end{array}$ & $\begin{array}{l}\text { Constructive relations among the } \\
\text { buildings, paths and open spaces }\end{array}$ \\
\hline 3 & Hook Barton & 1996 & $\begin{array}{l}\text { Sustained } \\
\text { settlements: A } \\
\text { guide for } \\
\text { planners, } \\
\text { designers and } \\
\text { developers }\end{array}$ & $\begin{array}{l}\text { Open space network to manage } \\
\text { pollution and increase local } \\
\text { green space }\end{array}$ \\
\hline 4 & $\begin{array}{l}\text { Richard } \\
\text { Rogers }\end{array}$ & 1997 & $\begin{array}{l}\text { Cities for a } \\
\text { Small Planet }\end{array}$ & $\begin{array}{l}\text { Public area of social } \\
\text { disconcerting and mobility } \\
\text { factor }\end{array}$ \\
\hline
\end{tabular}

\section{RESEARCH METHODOLOGY}

The research method is descriptive - analytical or depth and to conduct this study the documentary method, SWOT table, as well as field observations are used. In documentary and data collection stage books, publications, presentations results are used. 


\section{URBAN PUBLIC SPACE}

Urban public spaces have always been a physical context for social interaction of people. Although qualitative and quantitative characteristics of urban spaces have changed over time and due to several different factors, always citizens and other users of the city need such a spaces. Urban public space should be a place for social interaction and collective life. According to Mitchel public spaces have a mission to increase social capital in communities, in the context of social interactions and exchanges which can be the basis for development and formation of individual and social identity (Mitchel, 1996).

Urban space in general concept is the interaction between relationships and behaviors. It means that it in addition to being a location for the proximity of individual identity, in the urban life it is as the most important factor for authentication and affects human behaviors and relationships. Additionally, urban space as a public space is the location of the emergence and survival of thoughts and individual and social desires of human beings that is the most important center of shared perceptions of men and perhaps that's why it has important role in the development of human societies (Sadri, 2006). What is value in the knowledge of urban design for urban open space is the social and interactive role that this space plays in the social life of citizens. Urban spaces are a part of public and open spaces of cities that are the manifestation of the nature of social life where the citizens are present there. Urban space is a scene that collective life story open there. This space also is accessible for all people and they can work on it.

In this space there is the opportunity to break some social boundaries and to occur not pre-formulated encounters and people can mix together in a new social environment. This space should be managed by public organization in order to be in line with the public interest. Thus, the basic requirement for considering a public space as an urban space is that in which the social interaction takes place (Rafieian, Asgari, 2002).

In ancient Islamic city, the main form of leisure was sightseeing in the city. This sightseeing took place by attending in the city's public spaces. Markets, mosques, leaning, streets and squares during the Islamic Civilization were one of the ways to spend leisure time. The return to the nature has had a symbolic meaning and has also been a way to escape from the stresses of urban life and in the modern city it is still as one of the basic methods of "rest" as well. However, over time we have seen an increase in leisure spaces in the cities and citizens have less inclined to leave the city. In Iran in the early 20th century and the late Qajar era with the advent of the modern city, this issue emerged. National gardens, Zoo, cinemas, tea houses and parks in big cities demonstrated it. In recent decades with broad social and cultural changes that emerged, we have seen an increase in creating atmospheres for leisure (Pour Mousavi, 2001). Therefore, today planning to spend leisure time has close relation with urban planning, especially with land use planning because the spatial organizing and providing leisure facilities largely depends on the quantity and quality of urban spaces and their equipment (Mahdizadeh, 2006). Public space belongs to the public and the public gather in this space to interact, recreation, and leisure. The spaces include a wide range of public to private spaces. In other words, every activity and behavior has its own privacy and territory and mutually, every space has its own privacy as well. Needs whether material or psychological are satisfied depending on their properties in the private or public space. The spaces in our culture have their own hierarchy. Simply, urban spaces in terms of how to use them can be divided into three categories:

Private spaces: refer to that part of urban spaces that is owned and occupied or used privately by individuals. Spaces such as residential houses, courtyards and private gardens.

Semi-private / semi-public spaces: those spaces in the city that due to the limitation in their target and users are used by a particular group of people, spaces such as residential complexes and their areas, stadiums and exhibitions (Pakzad, 2007).

Public spaces is the manifestation of social relations, such spaces as new social mentality revealing area has particular importance in urban scale. Public spaces are the place for "seeing and being seen" people and are very important in the analysis of social life. In fact, urban spaces can change the type 
and amount of social relations by changing the people's behavior patterns. Urban public space converts the city from the dried and artificial place to a place to live (Saraei, Roustaei, Ashnavi, 2012). Surely, the vitality of cities and their continued dynamism depends on how citizens attend in it. Public spaces provide an important part of the citizen's needs especially their leisure needs. Finally, spending leisure time in urban life regardless of public spaces is meaningless (Madanipour, 2009). Therefore, before any planning for leisure the recognition of urban public spaces' features makes us more closer to this matter, because spending leisure time as any individual and social activity requires physical environment that can satisfy mental and activity needs. In the meantime, urban qualified public spaces can meet many needs of leisure time, cities of Iran physically have similar features, in many of them. In most of them, the old structure of the city is crumbled with the development of the city and the most use of the cars, and the new structure of the city is developed with unbalanced growth in different areas (Pour Mohammadi, Sobhani, 2009). On the other hand, the imbalance in social aspects and collective centers of city is causing social problems that one of them is the lack of suitable space for leisure time for people, especially young people. Reviewing the social spaces and recommending strategies to promote the quality of available social spaces in the urban context can reduce the existing problems (Arablu, Dashti Shafiei, 2012). However, different areas of sports, recreation and operation in cities are created for people of different ages to spend leisure time, the public qualified spaces of city as a behavioral setting can meet many needs of leisure time.

The concept of behavioral setting can be used to analyze the relationship between urban spaces and leisure time. Behavioral or location - behavioral setting is an element to analyze the environment and explains the dependency and coordination of both concepts of the location and activity.

\section{PUBLIC SPACE DESIGN REQUIREMENTS}

In order to benefit more from a physical environment, the physical environment should have the special meaning and physical characteristics. Regarding the urban public spaces and spending leisure time, it is expected that these spaces to be designed in a way that with specific requirements and features, provide the area for suitable function and presenting appropriate behaviors of spending leisure time in the physical environment. The current patterns in urban public spaces include leisure, sport, social interaction and so on. Hence, urban public spaces should have the condition for creating the behaviors. In other words, the urban public spaces should be designed in a way that to be compatible with the activities that have been done there. The following design requirements can be divided into three general groups:

\section{DEVELOPING AND FACILITATING SOCIAL INTERACTIONS}

The physical environment can be considered as an important component in human interaction with others. Human as an organized, dynamic and prone to learning system is able to correct the behavior in dealing with the environmental changes. Social interaction depends on the individual's social role and his relations in the group. Every social interaction has a condition and occurs in the specific place and time period. Therefore, the social interaction is limited to the spatial and temporal divisions. Some of these roles takes place with face-to-face relation and in larger groups, with speaking, appearance and condition of the body. In any case, its location and characteristic is an important issue in the process of social interaction. In general, proximity, homogeneity, density, success and purpose are the primary factors that shape the interaction among people and can lead to the cooperation and competition (Falahat, Kalami, 2008). Patterns of social interaction and functionality of the built environment are important because there is a close relationship between the social interaction and dependency of people to the made social and public environment. Another important environmental factor affecting social interaction is the number of people to contact in a finite spatial area.

Altman believes that the good social contact rate of people differs in different states and even at different times of day and individuals mostly use the privacy monitoring mechanisms such as manipulating their physical environment and keep their social contacts at desired level. Urban public spaces also play an important role in providing social need, interact of people with each other and development of personal and social relationships. Given that the interactions and social relations increase in urban spaces and leisure, it is better the physical environment to be designed in a way that can provide the groundwork for the development of social interactions of people at the leisure time. 
Thus, public urban spaces with specific physical characteristics can have the capability to meet the social needs of individuals and with the right conditions facilitate the suitable conditions of incidence of social relations (Khademolhosseini, Safikhani, 2011).

\section{CREATING A SENSE OF SECURITY AND PSYCHOLOGICAL AND PHYSICAL COMFORT}

One of the conditions necessary for urban public spaces for optimal performance and facilitating the appropriate behaviors presentation in leisure time is the existence of physical and psychological security and comfort and using this feature by users of public space so that the public space by having these conditions in different psychological levels suppliers specific behaviors in individual and will provide the homology of behavior and environment. Since the incidence of any behavior of any person is the result of his thoughts and mental and emotional issues thus, with a sense of security by a person in an urban space as a behavioral setting, the possibility of the incidence of positive behaviors and activities along with relaxation and enjoyment is expected of a person. By the nature of leisure activities, these activities are optional therefore, their occurrence primarily need physical and psychological comfort. Accordingly, in the design of public spaces for leisure time particular attention should be paid to this important matter and the assistance of all users should be provided according to their physical and psychological circumstances as much as possible so that generally by creating the right conditions the proper use and comfort were achieved. To achieve this issue, the public urban spaces should be coincident with human's physical and psychological needs (Falahat, Kalami, 2008).

\section{CREATING A SENSE OF ENJOYMENT, SATISFACTION AND BELONGING}

Design quality of urban public spaces as a behavioral base for leisure plays an important role in the satisfaction of people. How to spend leisure time differs based on the views, expectations and choice of people. But what seems to be common in most people is paying attention to the pleasure and benefit of these times. A sense of enjoyment will occur when a person reaches to the relative limit of physical and mental basis and to be free from beneficial issues. Thus, considering this factor is essential in urban public spaces for leisure time and this can not be achieved unless by designing spaces according to the social status and age of people and based on the interests, needs and current activities of people and creating the homology between urban public spaces (physical environment) and human behaviors. In other words, in these spaces consistent relationship is created between the behavior of people and place (Falahat, Kalami, 2008).

\section{CASE STUDY}

The approximate date of Chahar Bagh Street construction returns to the year 1000 AH (1591 AD). The street was originally constructed as a recreational street that in addition to social status has had governmental functions such as reading the instructions and orders of government. In Figure 1 the map of area of Chahar Bagh and Naghshe Jahan Square and the old context of Isfahan city can be seen. 


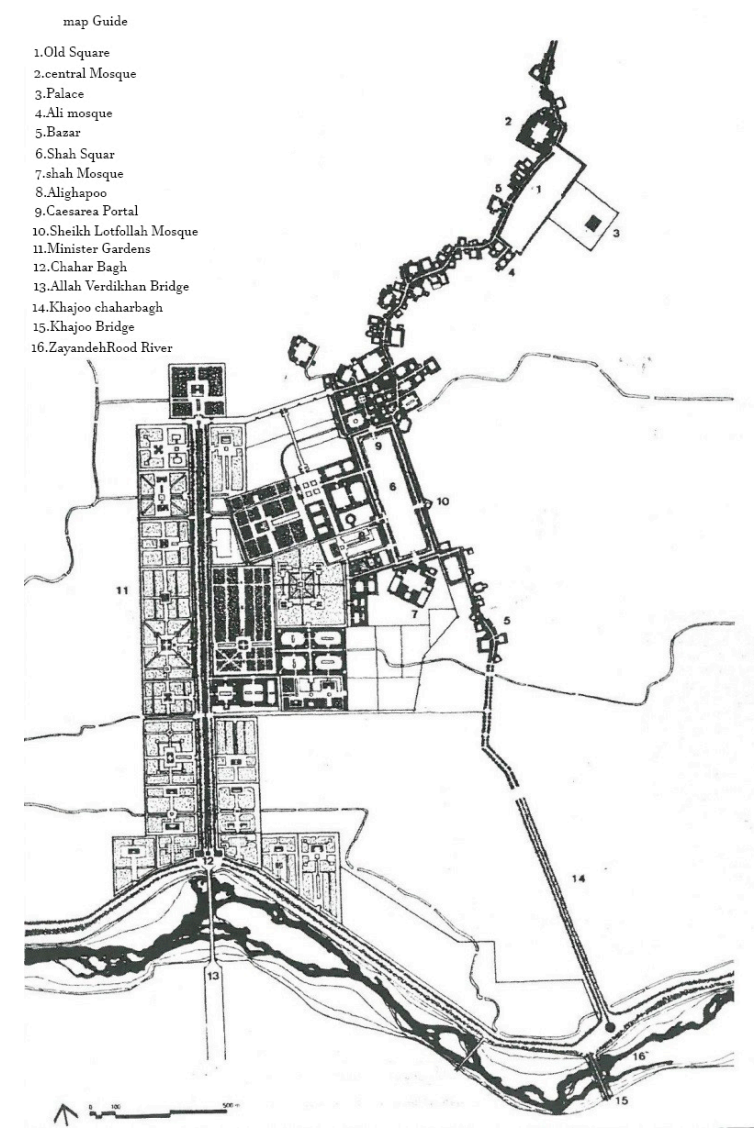

Figure 1. The map of area of Chahar Bagh and Naghshe Jahan Square and the old context of Isfahan city (Aedalan, Bakhtiar, 2001)

\section{THE QUALITY OF URBAN PUBLIC SPACES}

Quality is a vague term that each of theorists has presented different definitions, for example Schoomaker defines the quality of life as "satisfaction of everyone with life" (Schoenburn, 2002) or cutter knows the quality of life as "an individual's happiness or satisfaction with life and the environment" which including the needs and desires, aspirations and preference of lifestyle and other tangible and intangible factors that totally determine the well-being. But Marans has more precise definition, $\mathrm{He}$ argues that the spatial quality like public open space is a subjective phenomenon that everyone has a different perception of that space. Many studies show that urban open space depends on various aspects of quality of life such as physical and mental health, social interaction, and the crime rate, and economic value of the property. When the quality of urban space will be upgraded we can see the increase of individuals' presence in space and this leads to the creation of location sense in citizens and space monitoring which ultimately will lead to the sustainability of urban space.

\section{CRITERIA FOR THE QUALITY OF URBAN PUBLIC SPACE}

Mathew Carmona in his book entitled "Public places - Urban Spaces" in 2003, divides criteria of the quality of urban space into seven sections that are compiled in Table 2. After introducing them, criteria of the quality of urban spaces is studied in the case study.

Table 2. Matching sub-criteria for the quality of urban public spaces (Carmona, \& Tizol, 2007)

\begin{tabular}{|c|l|l}
\hline Row & $\begin{array}{l}\text { criteria of the quality of } \\
\text { urban space }\end{array}$ & $\begin{array}{l}\text { The study of quality criteria in top Chahar Bagh Avenue in } \\
\text { Isfahan }\end{array}$ \\
\hline 1 & availability & This street is perpendicular to the axis of Zayanderud. \\
\hline
\end{tabular}




\begin{tabular}{|l|l|l}
\hline & & $\begin{array}{l}\text { Design and principles of making street or branching streets } \\
\text { of Chahar Bagh Street is somehow that whatever the city } \\
\text { becomes more widespread, is indirectly influenced by the } \\
\text { historical axis. Now the street is one of the most crowded } \\
\text { axis of the city. }\end{array}$ \\
\hline 2 & Hard and soft space & $\begin{array}{l}\text { Chahar Bagh Avenue is symbolic and indicator that its } \\
\text { indicator element can not be simply separated. Chahar Bagh } \\
\text { Mosque, Azadi Square, thirty-three bridges, Revolution } \\
\text { Square, Imam Hussain (AS) Square and so on are considered } \\
\text { as its key elements and indicator. }\end{array}$ \\
\hline 3 & Public Space & $\begin{array}{l}\text { The existence of commercial axis in the body of } \\
\text { Chaharbagh increased its bustle and traffic. } \\
\text { Almost any time of the day, the street is not empty of people } \\
\text { and vehicles that this issue in addition to the creation of } \\
\text { traffic problems will lead to gradual destruction of historical } \\
\text { monuments in this place. }\end{array}$ \\
\hline 4 & Safety and Security & This street has a relatively high security. \\
\hline 5 & Urban Landscape & $\begin{array}{l}\text { Due to the location of the mentioned street in the historic } \\
\text { axis of Isfahan city and proximity to valuable sites, it has } \\
\text { proper vision in places such as thirty-three bridges that } \\
\text { causes to the recognition of pavement and street direction. }\end{array}$ \\
\hline 6 & Mixing and density & $\begin{array}{l}\text { High human density, low residential density along with high } \\
\text { commercial density are seen in the body of Chaharbagh. }\end{array}$ \\
\hline 7 & Inclusiveness & Studied urban space is an inclusive space. \\
\hline
\end{tabular}

\section{SOCIAL INTERACTIONS IN URBAN PUBLIC SPACES}

An space is "urban space" in which "social interaction" occurs. Urban public space should be conducive to enhancing social relationships. For this purpose, paying attention to the human dimensions in today's cities has been considered more and this policy is very effective on improving social relations capacity in society and then in the region. Human being, regardless of race, age or status, is interested in creating social interaction in public space.

Urban space in general concept is the interaction between relationships and behaviors. Urban space as a public space is where the individual and social thoughts and desires of humans are emerged namely, is the most important center of human's common perception and therefore, plays an important role in the development of human societies (Sadri, 2006). The communications between social interactions and stability in the public spaces of the city are analyzed in this way that the social interaction promotion increases the likelihood of the occurrence of events and collective memories that leads to the creation of location sense in space and consequently, sustainability of urban space.

\section{CRITERIA FOR SOCIAL INTERACTIONS}

Jan Gehl (1996) in his book entitled "Life among buildings" believes that by designing and with some regional, climatic and social limitations it is possible to influence the number of space users, the durability of practices and how to expand them in the environment. In his view outdoor activities in open public places can be divided into three categories which according to the Chahar Bagh Street of Isfahan city these criteria are set in Table 3 .

Table 3. Matching sub-criteria of social interactions in urban space

\begin{tabular}{|l|l|l|}
\hline Row & Criteria of social interactions in urban space & $\begin{array}{l}\text { Review of criteria of social interactions in top } \\
\text { Chahar Bagh Street of Isfahan city }\end{array}$ \\
\hline 1 & $\begin{array}{l}\text { Activities necessary } \\
\text { (Activities that are more or less compulsory }\end{array}$ & $\begin{array}{l}\text { - A lot of people for the sole purpose of going to } \\
\text { work every day pass Chahar Bagh Avenue. }\end{array}$ \\
\hline
\end{tabular}




\begin{tabular}{|l|l|l}
\hline & $\begin{array}{l}\text { and include daily activities such as traveling } \\
\text { to work and school or shoping. Individuals in } \\
\text { any circumstances have to carry out these } \\
\text { activities.) }\end{array}$ & $\begin{array}{l}\text { - For the trade body of the current Chaharbagh, } \\
\text { everyday many people come to this urban space for } \\
\text { shopping. } \\
\text { - Because of the many public transportation stations } \\
\text { in the field of Azadi, Enghelab, Imam Hussein (AS) } \\
\text { and Shohada people are forced to cross the street. }\end{array}$ \\
\hline 2 & $\begin{array}{l}\text { Optional Activities } \\
\text { (Dot not have a critical aspect and are done } \\
\text { in the favorable conditions. Otherwise people } \\
\text { do not see the requirements to do them, such } \\
\text { as recreational activities) }\end{array}$ & $\begin{array}{l}\text { - Having regard to the current function of Chahar } \\
\text { Bagh Street, this space could lead to the formation } \\
\text { of optional activities such as tourism. } \\
\text { - Because of cinemas in the body of the current } \\
\text { Chaharbagh, everyday many people come to the } \\
\text { urban space to watch the film. }\end{array}$ \\
\hline 3 & $\begin{array}{l}\text { Social activities } \\
\text { (Doing these activities is dependent on the } \\
\text { presence of other people in space and } \\
\text { performing them is not possible except in } \\
\text { collective form. }\end{array}$ & $\begin{array}{l}\text { - Street Chaharbagh is one of the spaces where the } \\
\text { the social activities of citizens such as mourning and } \\
\text { protests are done there. }\end{array}$ \\
\hline
\end{tabular}

\section{ANATOMY OF URBAN PUBLIC SPACE}

It can be possible to influence the activity pattern in urban public spaces through physical environment designing. Despite the regional, climatic and social limitations the number of events and people who use public space and the time of doing an activity can be increased (Gol, 2008).

Urban space as a field of diverse events occurrence contains elements, components and diverse information that the urban life speed and perception can be reduced by physical organization of the space where the possibility to benefit from the relaxation and comfort is provided there (Reza Zadeh, 2002) and this creates a sense of place and finally, leads to space stability.

\section{PHYSICAL CRITERIA OF URBAN PUBLIC SPACE}

Pakzad (2006) in his book entitled "theoretical foundation and urban design process" states the most important physical criteria of urban space in four cases that according to the case study these criteria are presented in Table 4.

Table 4. Matching physical sub-criteria of urban public space

\begin{tabular}{|c|l|l}
\hline Row & $\begin{array}{l}\text { Physical criteria of } \\
\text { urban space }\end{array}$ & Review of physical criteria \\
\hline 1 & Floor & $\begin{array}{l}\text { - Mosaic is the main materials used in flooring of sidewalks of the } \\
\text { streets, apart from the intersections. } \\
\text { - Uniformity of flooring and lack of attention to the aggregate } \\
\text { points, pause and ...so on. }\end{array}$ \\
\hline 2 & Body & $\begin{array}{l}\text { - The ratio of body height of street to the space between the street } \\
\text { is almost } 1 \text { to } 7 \text {. The width of the sidewalk of Chahar Bagh Street } \\
\text { on average is 3 meters that due to the height of walls closeness is } \\
\text { created to the walk space and also walls against atmospheric } \\
\text { effects such as rain and wind provide adequate protection for } \\
\text { pedestrians. }\end{array}$ \\
\hline 3 & Roof & $\begin{array}{l}\text { - Urban open spaces have no roof and and sky plays the ceiling } \\
\text { role for these spaces. }\end{array}$ \\
\hline 4 & $\begin{array}{l}\text { Elements deployed in } \\
\text { space }\end{array}$ & $\begin{array}{l}\text { - Designed elements in the urban space, across the street Sheikh } \\
\text { Bahai, have been in accordence with the city's history. } \\
\text { - Suitable spatial distribution of urban furniture elements }\end{array}$ \\
\hline
\end{tabular}


With regard to the issues raised in this section, the relationship among the three pillars of quality of urban space, social interactions and anotomy of urban space, and the sustainability of urban space can be justified to the relationship that is shown in Figure 2.

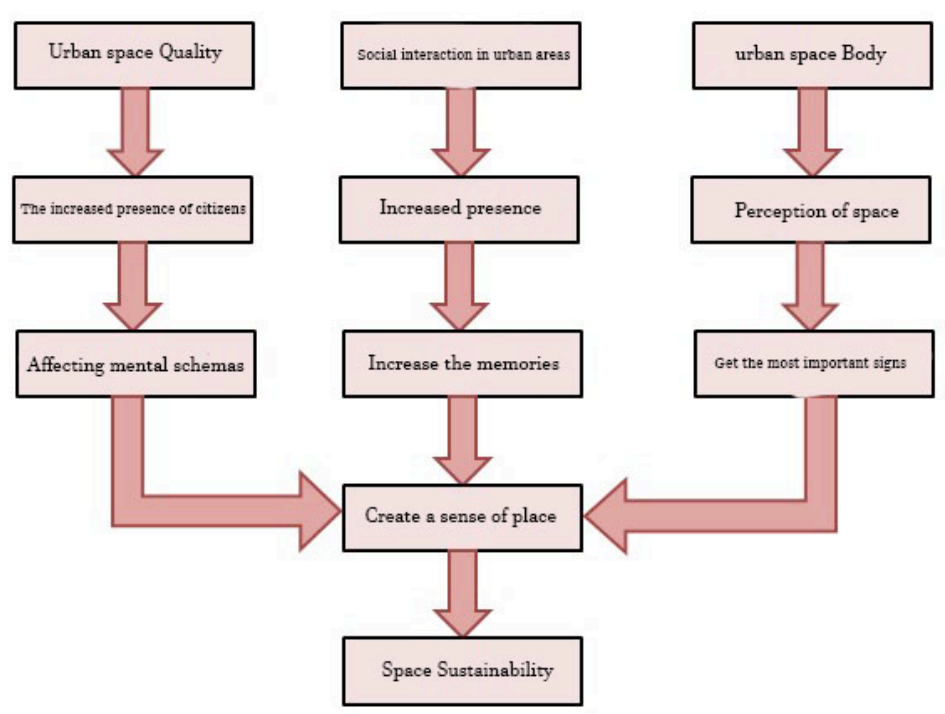

Figure 2. The relationship among the three pillars of quality of urban space, social interactions and anatomy of urban space, and the sustainability of urban space The integrated analysis of the status quo

Initially the integrated analysis of the status quo and review of the strengths and weaknesses opportunities and threats about three axes including quality, social and physical interactions of urban space in Chahar Bagh Street are presented in Table 5.

Table 5. Integrated analysis of the status quo and assessing the strengths and weaknesses opportunities and threats

\begin{tabular}{|l|l|l|l|l}
\hline Threats & Opportunities & Weaknesses & Strengths & \\
\hline T1: The & O1: The & W1: lack of & S1: Locating in & Quality of urban \\
likelihood of & possibility to & definition and & the historical & space \\
occurrence of & maintain good & separation of & center & \\
crime in the & views to bodies of & specific routes, & S2: proximity to & \\
hours after & indicator & including the route & the historical & \\
midnight & architecture such & of the disabled and & monuments & \\
& as the Dome of, & veterans & such as the & \\
& Chahar Bagh & W2: lack of & thirty-three & \\
& school, because of & functional and & bridges and ... & \\
& the relatively low & spatial organization & S3: The \\
& height of & ex temporary & existence of & \\
& buildings to the & activities including & different & \\
& street & the retail & applications to & \\
& & & meet user's & \\
& & & & \\
& & &
\end{tabular}




\begin{tabular}{|c|c|c|c|c|}
\hline $\begin{array}{l}\text { T2: Limiting } \\
\text { activities to } \\
\text { essential } \\
\text { activities. } \\
\text { T3: The } \\
\text { possibility of } \\
\text { forgotten } \\
\text { cultural users of } \\
\text { attractive } \\
\text { population such } \\
\text { as theaters }\end{array}$ & $\begin{array}{l}\text { O2: The } \\
\text { possibility of } \\
\text { cultural and } \\
\text { tourist attractions } \\
\text { users on the upper } \\
\text { floors. } \\
\text { O3: The } \\
\text { possibility of } \\
\text { creating spaces } \\
\text { that are reserved } \\
\text { for pedestrian } \\
\text { traffic until } \\
\text { pedestrians have } \\
\text { more time to } \\
\text { attend in the } \\
\text { environment. }\end{array}$ & $\begin{array}{l}\text { W3: uniformity and } \\
\text { coldness painting of } \\
\text { flooring streets and } \\
\text { sidewalks and lack } \\
\text { of attention to rally } \\
\text { and pause points }\end{array}$ & $\begin{array}{l}\text { S4: The } \\
\text { existence of } \\
\text { dynamics in } \\
\text { Chahar Bagh } \\
\text { Street as one of } \\
\text { the city's } \\
\text { historic public } \\
\text { spaces } \\
\text { S5: The } \\
\text { existence of } \\
\text { street vendors } \\
\text { that can increase } \\
\text { the dynamism of } \\
\text { street. }\end{array}$ & $\begin{array}{l}\text { Social } \\
\text { interactions }\end{array}$ \\
\hline $\begin{array}{l}\text { T4: The } \\
\text { possibility of } \\
\text { demolition and } \\
\text { ravages in the } \\
\text { face of the walls } \\
\text { because of } \\
\text { interference and } \\
\text { extensions of } \\
\text { users in the wall }\end{array}$ & $\begin{array}{l}\text { O4: The } \\
\text { possibility of } \\
\text { creating sidewalks } \\
\text { due to their } \\
\text { placement in the } \\
\text { historic cultural } \\
\text { center }\end{array}$ & $\begin{array}{l}\text { W4: The existence } \\
\text { of down and } \\
\text { heterogeneous users } \\
\text { on the walls. such } \\
\text { as pharmacy, deli, } \\
\text { clothing, pastry } \\
\text { shop. } \\
\text { W5: Lack of } \\
\text { coordinated policy } \\
\text { and principles on } \\
\text { viewing walls and } \\
\text { visual disturbances } \\
\text { in this area }\end{array}$ & $\begin{array}{l}\text { S6: The } \\
\text { existence of } \\
\text { valuable wall } \\
\text { with old and } \\
\text { historical } \\
\text { identity } \\
\text { S7: The } \\
\text { existence of } \\
\text { decorations in } \\
\text { brick and tile } \\
\text { work in wall } \\
\text { S8: The } \\
\text { existence of } \\
\text { almost uniform } \\
\text { skyline in the } \\
\text { body of city } \\
\text { S9: Almost } \\
\text { identical } \\
\text { physical form in } \\
\text { the walls }\end{array}$ & Body of space \\
\hline
\end{tabular}

\section{CONCLUSION}

Here, by analyzing the sustainability criteria in urban space, tips are provided for readout of Chahar Bagh Street which has tried to increase the stability of urban historical space by a comprehensive overview and based on the offered criteria and sub-criteria.

Table 6. Chahar Bagh Street readout Guide

\begin{tabular}{|l|l|l}
\hline Chahar Bagh Street readout Guide & Sub-criteria & $\begin{array}{l}\text { Sustainability criteria in } \\
\text { urban space }\end{array}$ \\
\hline $\begin{array}{l}\text { - Building sidewalk in the streets of Chahar Bagh in } \\
\text { Isfahan city and placing suitable vehicles for cargo } \\
\text { to the market and shops lining the streets and ... } \\
\text { - Observing principles and criteria of making } \\
\text { appropriate the urban spaces for the disabled and }\end{array}$ & Accessability & \\
\hline
\end{tabular}




\begin{tabular}{|c|c|c|}
\hline $\begin{array}{l}\text { veterans } \\
\text { - Creating a dedicated path for bicycles. } \\
\text { - Allowing the emergency vehicles (police, } \\
\text { ambulance, fire, transportation of money, etc.) to } \\
\text { enter the street through a controlled one-way }\end{array}$ & & \\
\hline $\begin{array}{l}\text { - Trying to create a soft spaces through the use of } \\
\text { transparent and unobstructed view materials } \\
\text { - Ability to influence the field. } \\
\text { - Minimizing the hard spaces in order to understand } \\
\text { the space better }\end{array}$ & $\begin{array}{l}\text { Hard and soft } \\
\text { space }\end{array}$ & \\
\hline $\begin{array}{l}\text { - The creation of tourism attractive activities such } \\
\text { as museums, cultural-recreational centers and } \\
\text { servicing }\end{array}$ & Public space & \\
\hline $\begin{array}{l}\text { - Notification in order to highlight the events and } \\
\text { activities in city center } \\
\text { - Creating behavioral bases in accordance with } \\
\text { urban space } \\
\text { - Creating the necessary spatial bed for the } \\
\text { activities of vendor, theatrics, and so on } \\
\text { - The creation of necessary facilities for holding the } \\
\text { periodic outdoor exhibitions, musical performances } \\
\text { and street performances, ceremonies, cultural- } \\
\text { religious gathering }\end{array}$ & Social activities & $\begin{array}{l}\text { Social interactions in } \\
\text { urban space }\end{array}$ \\
\hline $\begin{array}{l}\text { - The elimination of pedestrian movement barriers } \\
\text { in space } \\
\text { - Short distance to public transport stations } \\
\text { - Single-level space }\end{array}$ & $\begin{array}{l}\text { Effective body } \\
\text { in social } \\
\text { interactions }\end{array}$ & \\
\hline $\begin{array}{l}\text { - To emphasize wall street milestones (such as } \\
\text { cinema) to be implemented in reflect flooring and } \\
\text { with different designs. }\end{array}$ & Floor & Body of urban space \\
\hline $\begin{array}{l}\text { - Providing the program of the maintenance and } \\
\text { cleaning of walls } \\
\text { - All elements or materials added in the foundation } \\
\text { that are not compatible with the main body should } \\
\text { be cleared and replaced with appropriate materials. } \\
\text { - All entrance doors and windows of shops should } \\
\text { be replaced with suitable and new materials. } \\
\text { - Walls should be designed and implemented with } \\
\text { conventional lighting monuments. } \\
\text { - All visible objects such as gas pipes, electricity } \\
\text { and telecommunications cables, air conditioner } \\
\text { channel, and so on should be cleaned and to be } \\
\text { replaced in the right place with the right design. }\end{array}$ & Body & \\
\hline $\begin{array}{l}\text { - Creating dense vegetation cover and in the volume } \\
\text { form in the middle of the street } \\
\text { - Urban furniture in the proposal sidewalks' space } \\
\text { should be designed and implemented limited to } \\
\text { street and to be coincide with the street building } \\
\text { time period (in terms of appearance) such as } \\
\text { benches, trash, basic lighting, billboards .... }\end{array}$ & $\begin{array}{l}\text { Deployed } \\
\text { elements in } \\
\text { space }\end{array}$ & \\
\hline
\end{tabular}


This paper proposed the urban space as a place of interaction and physical visualization of dialogue of various environmental components that the sustainable development and urban space can be based on it and with matching criteria in the Charbagh Strret of Isfahan city it is concluded that all three factors of quality of urban space, social interaction in urban space as well as urban space skeleton play key role in the sustainability of space and in other words, responding to the needs of citizens through influencing the mental aspects of sustainability and creating a sense of place in the space.

\section{REFERENCES}

Aedalan, N., \& Bakhtiar, L. (2001). A sense of unity, First edition, Tehran: Publication of soil, 168. Carmona, M., \& Heath, T., and Tysdl, A. (2003). Public places of urban spaces, Trans: Gharaei, F., Shoukohi, M., Ahari, Z., Salehi, E., Tehran, University of Arts, First Edition.

Kashanijo, Kh. (2010). Recognition of theoretical approaches to urban public spaces, Journal of identity of city, Fourth Edition.

Carmona, M., \& Tizol, A. (2007). Reading urban design concepts, Trans: Zekavat, K., Tehran, Tehran University, Third Edition.

Falahat, M. S., \& Kalami, M. (2008). The impact of urban open spaces on the quality of leisure time of citizens, City Management Magazine, 22.

Gol, Y. (2008). Living in the space among buildings, Trans: Shima Shasti, Tehran, Jahad Daneshgahi Publication, First edition.

Khademolhosseini, A., \& Safikhani, M. (2011). The evaluation of physical factors limiting women in spending leisure time in urban areas 1 and 6 areas of comparative study, Tourism and Sustainable Development Conference, Islamic Azad University of Hamedan.

Madanipour, A. (2009). Urban space design, Trans: Mortezaei, F., Processing and Urban Planning Company.

Mahdizadeh, J. (2006). Strategic planning of urban development of recent global experience and its place in Iran, Tehran: Publication of Sima message Design and Publishing Company.

Mitchel, D. (1996). Introduction: Public space and the city. Urban Geography, 17 (2).

Pakzad, J. (2007). The urban spaces design guide in Iran, Tehran: Shahidi publication, Third Edition.

Pour Mohammadi, M.R., \& Sobhani, Z. (2009). Research on the assessing factors affecting the user's view of leisure in Tehran, Journal of Urban and Regional Studies and Research, First Edition, 1.

Arablu, F., \& Dashti Shafiei, A. (2012). The impact of contemporary public spaces of the city on leisure of seniors, First National Conference on ideas and new technologies in architecture, Tabriz.

Pour Mousavi, S. M. (2001). Citizen's participation and leisure programs, Tehran: society and culture publication.

Rafieian, M., \& Asgari, A. (2002). Senior and the need for planning urban spaces, The International Conference on Senior, Faculty of Social Welfare and Rehabilitation.

Rastbin, S., et al. (2012). The correlation between environmental quality and sustainability of urban life in the public arena, Bagh Nazar, 21.

Reza Zadeh, R. (2002). Time, speed and rhythm of city life, Urban Management Magazine, 9.

Sadri, H. (2006). Examining the role of urban spaces in the development of democracy, The first International Conference of Premier City, Premier Designs, Hamedan Municipality Civil Organization.

Saraei, M. H., Roustaei, M., \& Ashnavi, A. (2012). Factors affecting leisure in urban areas of regions of Iran. Case Study: Mashhad region, Regional Planning Quarterly, 7.

Schoenburn et al (2002). A survey second analysis about leisuretimes of American citizens. National centre of American Health. 